\title{
PEMBERDAYAAN MASYARAKAT MELALUI PEMANFAATAN TEKNOLOGI DALAM RANGKA MENINGKATKAN KUALITAS SUMBER DAYA MANUSIA DI DESA GUNUNG MENYAN
}

\author{
Eny Dwimawati ${ }^{1}$, Faheza Beliansyah, Salwa Afiah Zulfa ${ }^{2}$ \\ eny@uika-bogor.ac.id \\ Dosen Fakultas Ilmu Kesehatan ${ }^{1}$, Mahasiswa KKN Kelompok 53 Tahun $2018^{2}$
}

\begin{abstract}
ABSTRAK
Teknologi yang semakin berkembang pada saat ini, tidak dapat dipungkiri lagi banyak orang yang menggunakan teknologi sebagai alat untuk menyambung tali silaturahmi, berdagang maupun hal lainnya yang mencakup semua aktivitas manusia itu sendiri, baik secara individu maupun secara kelompok. Maka daripada itu, Perkembangan teknologi terjadi karena seseorang menggunakan akalnya untuk menyelesaikan setiap masalah yang dihadapinya, yang terjadi pada perubahan pola hidup manusia yang lebih pragmatis, hedonis, sekuler, dan melahirkan generasi instan namun juga mengedepankan efektifitas dan efisiensi dalam tingkah laku dan tindakannya. Kemajuan teknologi adalah sesuatu yang tidak bisa dihindari dalam kehidupan ini, karena kemajuan teknologi akan berjalan sesuai dengan kemajuan ilmu pengetahuan. Menurut Rosenberg (2001) (didalam Ananda 2015), ialah dengan berkembangnya penggunaan teknologi informasi ada 5 (lima) pergeseran dalm proses pembelajaran yaitu dari pelatihan kepenampilan, dari ruang kelas ke di mana dan kapan saja, dari kertas ke "on line" atau saluran, fasilitas fisik ke fasilitas jaringan kerja dan dari waktu siklus ke waktu nyata. Tujuan dari jurnal yang dibuat ini adalah untuk meningkatkan potensi yang telah tertanam sejak awal pada diri masing- masing warga yang memiliki potensi pencapaian sangat tinggi. Dalam pelaksanaan kegiatan di lapangan sebelumnya telah dilakukan observasi lapangan oleh semua mahasiswa KKN. Semua program dapat terlaksanadengan baik berkat kerjasama antar peserta KKN dengan masyarakat Kp. Kananga.
\end{abstract}

Keywords : pemberdayaan masyarakat, pemanfaatan teknologi, kualitas sumber daya manusia.

\section{PENDAHULUAN}

\section{Latar Belakang}

Kuliah Kerja Nyata (KKN) adalah suatu bentuk kegiatan mahasiswa yang merupakan cara interaksi mahasiswa dengan masyarakat dan lingkungan sekitarnya, lahir dari animo mahasiswa yang merasa perlu ikut serta dalam proses pembangunan. Pada hakekatnya merupakan perwujudan dari salah satu dharma perguruan tinggi, yakni pengabdian kepada masyarakat, yang bersifat lintas disiplin (interdisipliner) dan merupakan komponen keilmuan, teknologi dan seni secara aplikatif guna membentuk kehidupan masyarakat, utamanya di pedesaan. Hal tersebut bertujuan untuk membantu dan mendampingi masyarakat dalam pemanfaatan potensi Sumber daya Alam (SDA) lokal serta Sumber Daya Manusia (SDM), sehingga dapat mengatasi 
permasalahan masyarakat dalam kurun waktu tertentu.

Pada era globalisasi saat ini, penguasaan teknologi menjadi prestise dan indikator kemajuan suatu negara. Negara dikatakan maju jika memilki tingkat penguasaan teknologi tinggi (high technology), sedangkan negara-negara yang tidak bisa beradaptasi dengan kemajuan teknologi sering disebut sebagai negara gagal (failed Country). Berikut ini namanama negara yang memiliki penguasaan teknologi tertinggi:

\begin{tabular}{|c|c|}
\hline No & Nama Negara \\
\hline 1 & Finlandia \\
2 & Amerika Serikat \\
3 & Jepang \\
4 & Swedia \\
5 & Korea Utara \\
6 & Belanda \\
7 & Inggris \\
8 & Singapura \\
9 & Korea Utara \\
10 & Australia \\
\hline
\end{tabular}

Sumber:(http://top10newsworld.blo gspot.com/2018/09/13)

Pada satu sisi, perkembangan dunia IPTEK yang demikian mengagumkan itu memang telah membawa manfaat yang luar biasa bagi kemajuan peradaban umat manusia. Dari sinilah kami melihat dari kualitas dan kemampuan masyarakat yang berada di Kp. Kananga ini sangat tinggi. Teknologi yang mereka kuasai sedikitnya mereka mengetahuinya, dari mulai anakanak sampai dewasa ibu-ibu. Dari keahlian inilah yang mereka miliki kita berusaha lebih mengembangkan potensi yang mereka punya demi kualitas sumber daya manusia disana. Dengan demikian, kami kelompok mahasiswa yang ditempatkan di Desa Gunung Menyan Kecamatan Pamijahan berkewajiban bersama-sama dengan warga desa merealisaikan substansi dari KKN.
Dari hasil survey serta koordinasi, ada beberapa program/kegiatan item program kerja. Maka dari itu, pihak Universitas serta kelompok kami sangat mengharapkan partisipasi dari semua pihak pemerintah maupun masyarakat dalam rangka mendukung kegiatan ini dan demi terlaksananya pembangunan di pedesaan.

\section{Kondisi Wilayah}

Kampung Kananga merupakan salah satu kampung yang berada di Desa Gunung Menyan. Secara geografis kampung ini terletak di dataran tinggi Kabupaten Bogor. Dengan luas wilayah desa $214 \mathrm{Ha}$, yang terbagi menjadi $7 \mathrm{Rw}$. Dengan jumlah penduduk sekitar 600.000 orang. Adapun batasan- batasan wilayahnya:

Sebelah Utara

: Cimayang

Sebelah Selatan

: Cibening/ Gunung Picung

Sebelah Timur

: Cibening

Sebelah Barat

: Pasarean/ Situ Udik

Penduduk Kampung Kananga sebagian besar memiliki usaha Home Industry dan sebagian besar berprofesi sebagai Buruh. Angka kelahiran (Natalitas) di Kampung Kananga lebih tinggi daripada kematian (Mortalitas) yang dibuktikan dengan masih banyaknya anak-anak yang umurnya berkisar antara 0-12 tahun.

Potensi yang berkembang di Kampung ini adalah dalam bidang keagamaan, yaitu Marawis dan Tilawatil Qur'an (membaca Al-qur'an dengan irama) yang mayoritasnnya adalah Pelajar. Keahlian tersebut didukung dengan adanya Pondok Pesantren yang mengembangkan minat anak dalam bidang tersebut. Tingkat pendidikan rata-rata Kampung Kananga berada pada jenjang SMA. Kegiatan rutin Kampung Kananga antara lain: rapat 
Karang Taruna, Posyandu, yasinan, pengajian mingguan, rapat RT, kerja bakti dan TPA.

\section{METODE PENGABDIAN}

Tahapan pelaksanaan untuk kegiatan ini sebagaimana terlihat pada bagan Sebagai berikut :

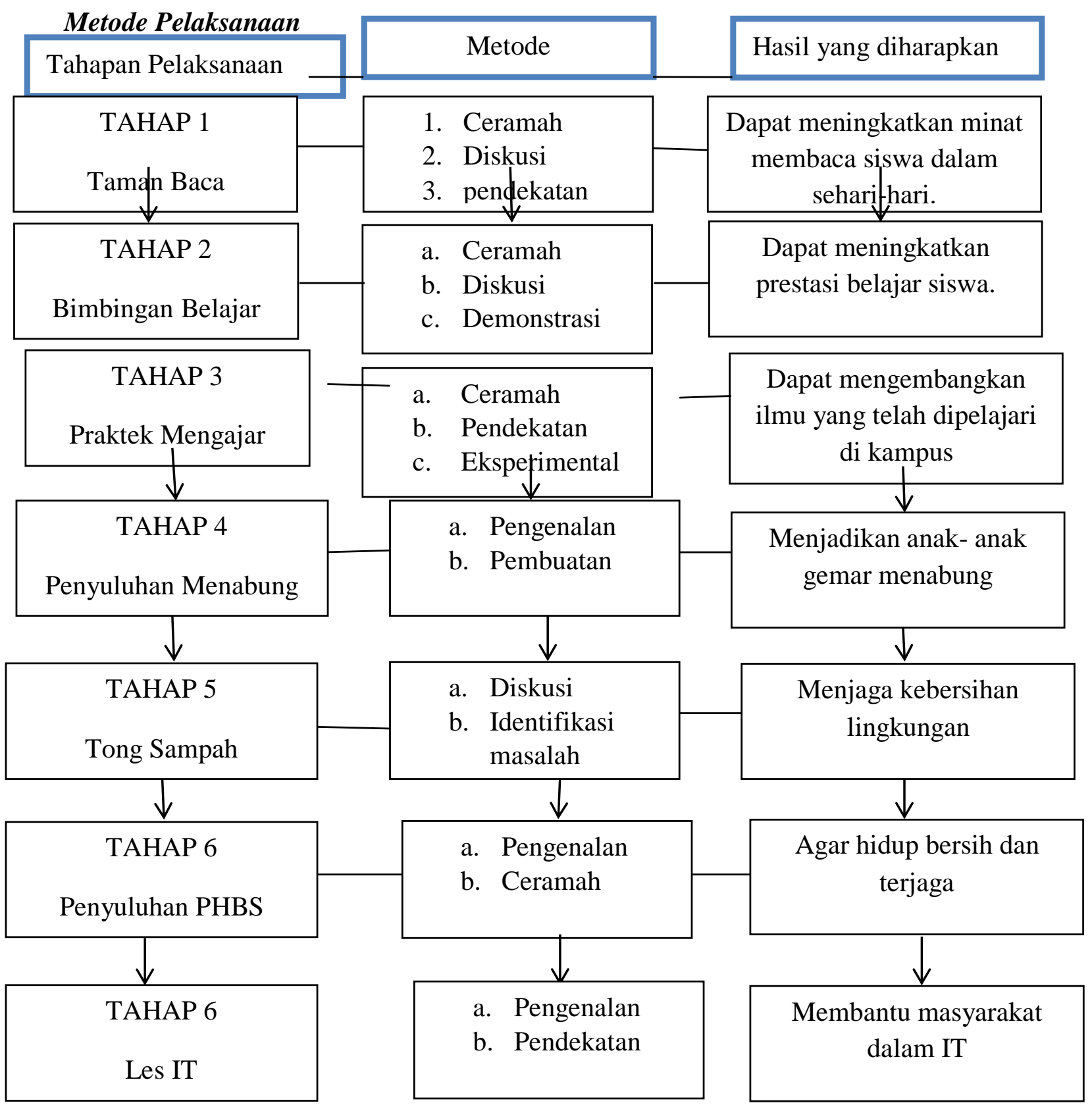




\section{Jadwal Kegiatan}

\begin{tabular}{|l|l|l|l|l|l|}
\hline \multirow{2}{*}{ No } & \multicolumn{1}{|c|}{ Kegiatan } & \multicolumn{3}{c|}{ Minggu } \\
\cline { 3 - 6 } & & 1 & 2 & 3 & 4 \\
\hline 1 & Penyusunan Rencana Kegiatan & & & & \\
\hline 2 & Penyusunan Struktur KKN & & & \\
\hline 3 & Sosialisasi rencana kegiatan & & & & \\
\hline 4 & Mengajar TPA/TPQ & & & \\
\hline 5 & Bimbingan belajar \& Taman Baca & & & & \\
\hline 7 & Upacara 17 agustus 1945 & & & & \\
\hline 8 & Idul Adha & & & & \\
\hline 9 & Mengajar di sekolah terdekat & & & & \\
\hline 10 & $\begin{array}{l}\text { Pengenalan Teknologi, Informasi } \\
\text { dan Komunikasi }\end{array}$ & & & & \\
\hline 11 & Penyuluhan PHBS & & & & \\
\hline 12 & Budaya menbung \& kreatifitas & & & & \\
\hline 13 & Pengajian pemuda/i & & & & \\
\hline 14 & Pembuatan Tong sampah & & & & \\
\hline 15 & Pengajian Ibu-ibu & & & & \\
\hline 16 & Pengajian Bapak-bapak & & & & \\
\hline 17 & Partisipasi dalam perlombaan 17 & & & \\
\hline 18 & Agustus & & & & \\
\hline 19 & Pes IT & & & & \\
\hline
\end{tabular}

\section{Metode Pendekatan}

Pendekatan yang dilakukan dalam

kegiatan ini adalah :

1. Pendekatan religius, yaitu pendekatan yang menggunakan nilai-nilai agama sebagai basis kegiatan. Pendekatan ini sangat penting karena permasalahan pemahaman radikalisme dalam masyarakat sangat dipengaruhi oleh faktor keimanan, pengalaman keagamaan, rasa tanggung jawab dan pengetahuan

2. Pendekatan organisasi, Hal ini sesuai dengan hasil penelitian Bahari (2010) dimana dia menemukan bahwa keterlibatan organisasi mempunyai pengaruh langsung terhadap toleransi.

3. Pendekatan berdasarkan karakter masyarakat, yakni pembinaan yang dilakukan akan disesuaikan dengan karakter masyarakat. Joyce dan Weil (1996) mengungkapkan bahwa model pendidikan yang relevan dengan perilaku sosial dan nilai adalah dengan banyak memberikan permainan peran. Hal ini dilakukan untuk memberi pengalaman riil kepada peserta didik tentang sesuatu yang dilakukan atau dirasakan oleh orang lain. Memang, dalam prakteknya, tidak seluruh aspek harus menggunakan permainan ini. Dalam beberapa hal, terdapat kegiatankegiatan yang hanya golongan tertentu untuk melakukannya. Sejalan dengan konsep Joyce dan Weil, cooperative learning yang digagas Slavin (2005) dapat digunakan untuk 
membangun kesadaran toleransi masyarakat. Hal ini karena penekanan dari konsep pendidikan ini adalah kerjasama yang mer upakan urat nadi toleransi. Dengan demikian, model pendidikan yang akan dibangun menggunakan dua konsep utama yaitu role playing model dan cooperative learning model.

4. Pendekatan kekerabatan, artinya bahwa pembinaan yang dilakukan senantiasa dikaitkan dalam rangka meningkatkan kesadaran akan pentingnya pendidikan, teknologi, kesehatan dan kreatifitas.

\section{Partisipasi Masyarakat dalam}

\section{Pelaksanaan Program}

Partisispasi masyarakat dapat dilakukan dalam kegiatan ini adalah sebagai berikut:

a. Mempersiapkan anak - anak yang bersedia mengikuti bimbingan belajar

b. Mempersiapkan anak - anak yang bersedia mengikuti perlombaan dalam memeriahkan 17 agustus 1945.

c. Mempersiapkan izin untuk mengadakan pelatihan mengajar

d. Mempersiapkan dalam hal acara Desa tahunan seblum dan sesuah 17 agustus 1945 .

e. Mempersiapkan tempat untuk pembinaan dan pelatihan.

f. Mempersiapkan tempat untuk penyuluhan menabung sejak dini

g. Mempersiapkan tempat untuk penyuluhan PHBS

h. Bersama-sama mengecat gapura Kampung Kananga.

\section{Langkah Evaluasi}

Evaluasi yang akan dilakukan terdiri dari:

1. Evaluasi proses, yang terkait dengan perencanaan, pelaksanaan dan monitoring kegiatan. Evaluasi proses akan dilakukan setiap pekan bersama dengan masyarakat.

2. Evaluasi hasil, yang akan dilaksanakan setelah kegiatan dilaksanakan. Evaluasi hasil ditujukan untuk menguji pemahaman masyarakat terhadap program kerja yang sudh dilaksanakan.

\section{REALISASI PROGRAM}

Pelaksanaan program kerja KKN merupakan realisasi dari rancangan program kerja yang tercantum di dalam matriks, yang idealnya harus sesuai dengan rancangan yang telah dibuat, akan tetapi pada kenyataan yang dihadapi di lapangan sering dihadapkan pada berbagai hambatan sehingga tidak semua program dapat dilaksanakan sesuai rancangan yang ada. Program kerja ini terdiri dari program kerja kelompok dan program kerja individu. Program kerja kelompok adalah kegiatan yang dilaksanakan lebih dari setengah jumlah seluruh anggota kelompok KKN, sedangkan program kerja individu adalah kegiatan yang dilaksanakan individu atau perorangan yang dibantu anggota lain, yang jumlah anggotanya kurang dari setengah jumlah seluruh anggota kelompok KKN. Di samping itu program individu dibagi menjadi program utama dan program penunjang.

Program utama adalah program yang dilaksanakan sesuai dengan kompetensi pelaksana, sedangkan program penunjang adalah program yang dilaksanakan untuk 
membantu program utama anggota lainnya. Sedangkan program insidental adalah program yang tidak tercantum dalam matriks dan merupakan program yang berkaitan dengan kegiatan partisipasi mahasiswa KKN di masyarakat. Berdasarkan rencana program kerja yang telah dibuat, dalam melaksanakan program kerja, waktu dan target pencapaian program kerja diusahakan sama dengan yang telah direncanakan, akan tetapi tidak menutup kemungkinan apabila antara pelaksanaan dengan rancangan terdapat perbedaan yang dikarenakan oleh situasi dan kondisi yang tidak sama dengan yang diharapkan atau adanya program-program lain yang ternyata lebih mendesak dan lebih dibutuhkan oleh masyarakat. Perbedaan-perbedaan yang terjadi tersebut dapat berupa pergeseran waktu pelaksanaan program dan penambahan atau pengurangan jumlah program kerja yang dilaksanakan.

\section{a. Keagamaan}

Hanipah (2016) Nilai- nilai agama Islam pada masa sekarang, telah mengalami suatu perubahan yang sangat pesat akibat dari pengaruh kemajuan ilmu pengetahuan dan tekhnologi. Tahap perubahan menjadi penopang dan sebagai persiapan yang mendasar untuk kehidupan dan perkembangan kepribadian anak di masa mendatang. Maka dari itu demi menjaga akhlak pemuda dan anak-anak perlu adanya benteng dengan kegiatan-kegiatan yang menyalurkan nilai-nilai agama dalam kehidupan sehari-hari.

Untuk merealisasikan pembentukan karakter yang bernilai keagamaan, maka kami membuat program berupa TPQ (Taman Pendidikan Al-Qura'an), bimbingan sholat untuk anak-anak, serta turut andil dalam menggerakkan pengajian rutinan pemuda.

\section{b. Pendidikan}

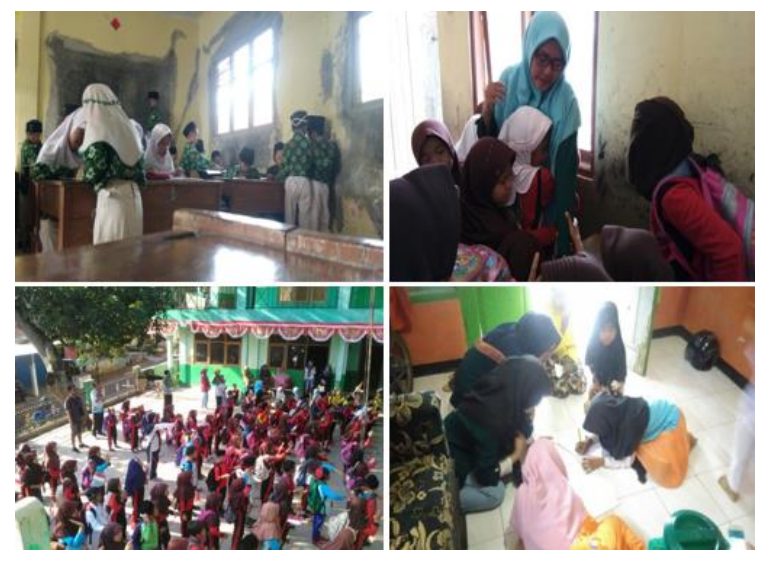

Budiati (2018) Pendidikan sebagai

tulang punggung pembangunan, mempunyai peranan yang sangat penting dalam mengasilkan pribadi-pribadi yang berkualitas. Kualitas sumber daya manusia yang mampu bersaing menjadi tuntutan utama dalam perkembangan teknologi. Dalam usaha meningkatkan kualitas pendidikan, salah satunya diperlukan, suatu gagasan serta tindakan yang tepat dan efisien untuk mengatasi rendahnya hasil belajar.

Maka dari itu disini kami mencoba untuk mewujudkan pendidikan itu menjadi sangat berarti bagi kehidupan mereka. Dengan memanfaatkan ilmu yang telah kami dapat dari hasil belajar di kampus, kami melaksanakan program belajar mengajar di sekolah MIS Raudlatul Thalibin, dan bimbingan Belajar, agr anak lebih giat lagi dalam belajarnya. 
c. Ekonomi

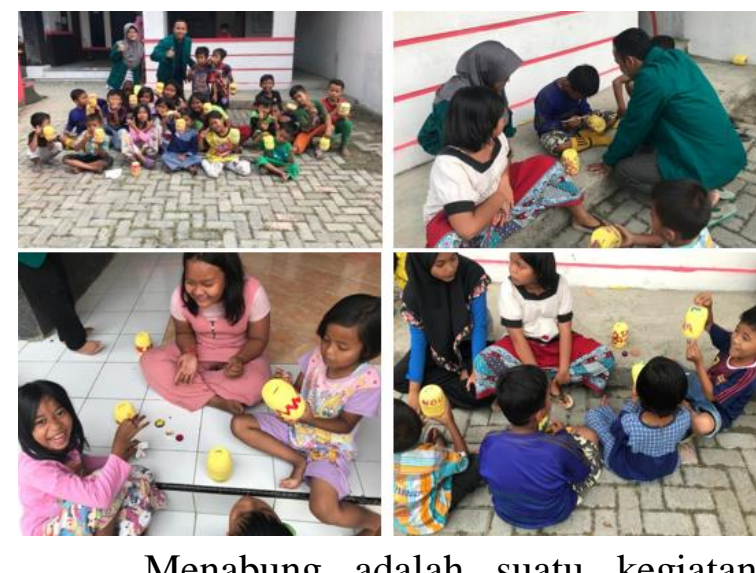

Menabung adalah suatu kegiatan atau aktifitas yan dilakukan dalam rangka menyimpan atau menyisikan uang. Menabung merupakan kegiatan yang baik untuk dipupuk sejak dini, karena dengan melatih menabung dapat memberikan dampak positif untuk kehidupan mendatang. Oleh sebab itu alangkah baiknya ti mulai menabung untuk anakanak. Kegiatan tersebut dapat dimulai dengan hal-hal kecil dimana si anak dapat diarahkan untuk dapat menyisihkan uang jajan tersebut ke dalam celengan.

Tujuan dari menabung:

1. Membiasakan menyisihkan uang

2. Membiasakan mengatur dan mengelola keuangan

3. Mendisiplinkan perencanaan keuangan

4. Sudah merencanakan dan mempersiapkan masa depan

Kegiatan sosialisasi atau menerapkan menabung sejak dini adalah kegiatan yang cukup penting agar dapat dipahami dan dimulai oleh anak-anak, dimana menabung sangat bermanfaat untuk masa depan, menyaadarkan dan memotivasi mereka untuk dapat dilakukan dengan sebelumnya memberikan pengertian terlebih dahulu.

Maka dari itu, kami selaku bagian dari bidang ekonomi mengadakan sosialisasi sekaligus mengajak anak-anak Kampung Kananga untuk berkreasi menghias celengan mereka sendiri agar mereka bersemangat untuk menabung dengan celengan dari hasil kreasi mereka sendiri.

\section{d. Kesehatan}

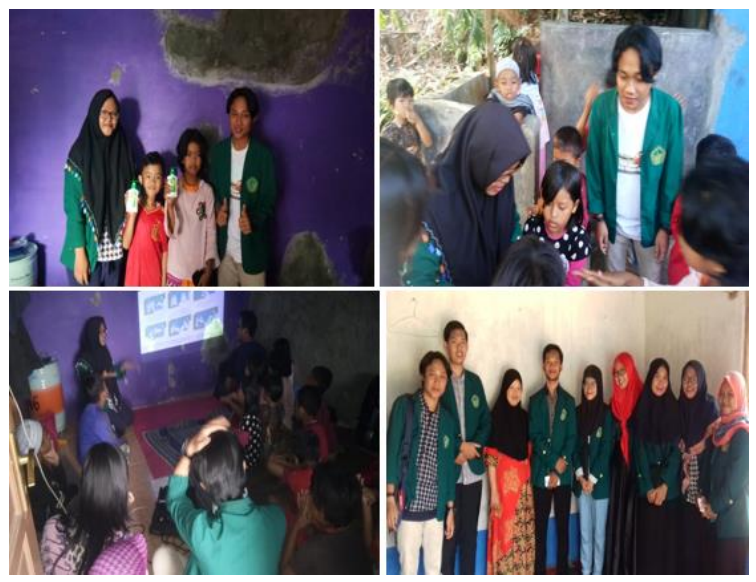

Perilaku Hidup Bersih dan Sehat (PHBS) adalah salah satu strategi yang dapat ditempuh untuk menghasilkan kemandirian dibidang kesehatan baik pada masyarakat maupun pada keluarga, untuk memberikan informasi dan melakukan pendidikan kesehatan. Tujuan dari PHBS meningkatkan masyarakat ber-PHBS disemua tatanan seluruh masyarakat. Menurut Eska dalam Jurnal Abdi Dosen Pemberdayaan kesehatan merupakan kegiatan penambahan pengetahuan yang diperuntukan bagi masyarakat melalui penyebaran pesan. Adapun manfaat dari PHBS itu sendiri ialah sebagai berikut:

1. Masyarakat meningkat kesehatannya dan tidak mudah sakit.

2. Anak tumbuh sehat dan cerdas.

3. Produktivitas kerja meningkat.

4. Terpenuhinya biaya pendidikan, pemenuhan gizi keluarga, dan meningkatkan pendapatan keluarga. 


\section{e. Teknik}

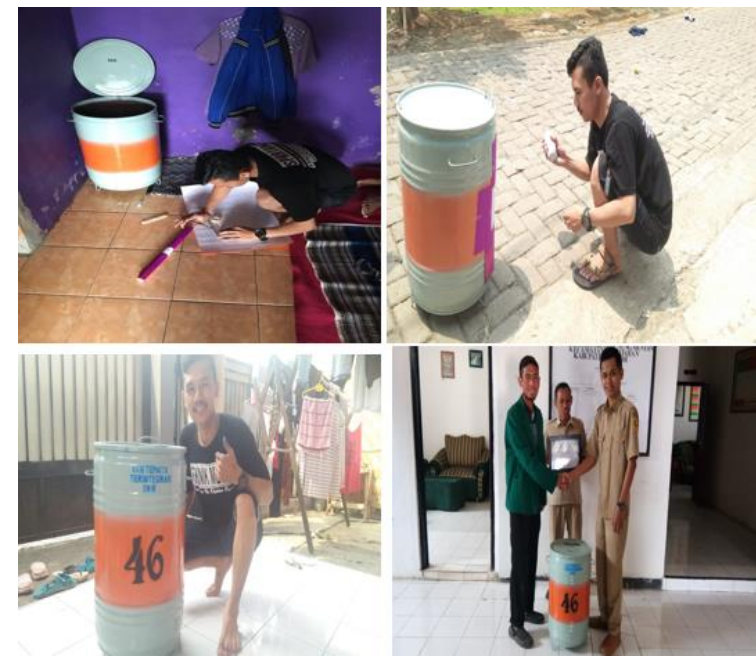

1. Pembuatan tong sampah.

Pembuatan program tong sampah ini bertujuan untuk Membantu menjaga kebersihan di lingkungan halaman kantor Desa Gunung Menyan dan sebagai kenangkenangan hasil KKN tematik terintegrasi 2018 Universitas ibn Khaldun Bogor di Desa Gunung Menyan. Bentuk kegiatan itu sendiri ialah dengan pertama membuat pola huruf dan angka sebagai simbol kelompok di lanjutkan dengan menghias tong dengan menyemprot kan warna dengan cat pilox. Dengan jumlah biaya yang telah dikeluarkan dalam program tong sampah ini ialah

Tong Sampah

Rp. $140.000,00$

Pilox 2 Buah

Rp. $32.000,00$

Karton 2 Lembar Rp. $\quad 5.000,00$

Pensil \& Penghapus Rp. $\quad 3.000,00$
Total
Rp. $180.000,00$
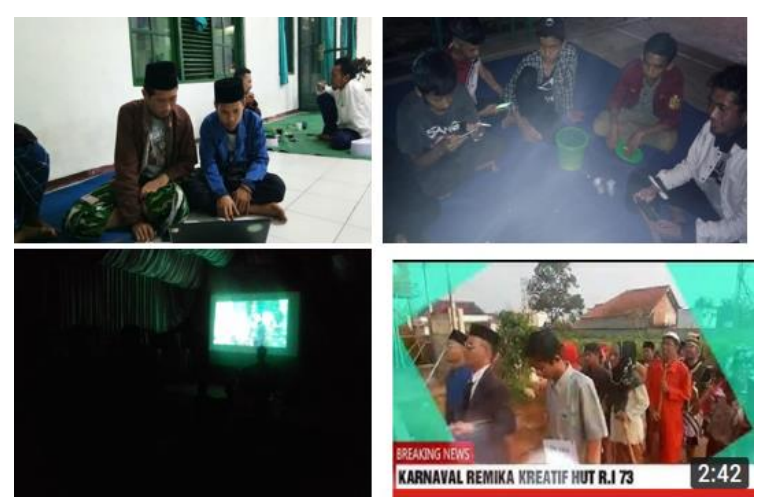

2. Les IT (Microsoft Word dan pembuatan video)

Les IT ini bertujuan untuk Membantu masyarakat belajar mengetik di komputer dan supaya dapat membantu warga ketika ada agenda yang membutuhkan pemberitahuan melalui media cetak. Tidak hanya itu Memberikan gambaran masa lampau dan semangat untuk orang tua yang dulu masih muda dan pemuda serta menjadi hiburan bagi warga.

Bentuk kegiatan tersebut antara lain: (1) Menampilkan photo kegiatan masa lampau dan video kkn 46 dan warga dalam proyektor;

Memberikan tugas dengan membuat cerita maupun membuat lembar penilaian untuk perlombaan agustusan, lalu mengaplikasikannya di Microsoft word; dan (3) Memberikan tugas untuk membuat video dan mengaplikasikannya di aplikasi pembuatan video melalui aplikasi lewat handphone. Link beberapa video yang diputar saat penaampilan acara puncak 17 Agustus pada tangal 31 agustus https://www.youtube.com/watch?v=bq8RPj 1TL7U

https://www.youtube.com/watch?v=C8rG9 $\underline{\text { PaeOak\& }=47 \mathrm{~s}}$

https://www.youtube.com/watch?v=rQZvy 9RQElo 


\section{KESIMPULAN}

Kesimpulan Tim KKN UIKA 46 tahun 2018 telah berhasil menyelesaikan program-program kerja KKN di Kampung Kananga, Desa Gunung Menyan, Kecamatan Pamijahan, Kabupaten Bogor, Jawa Barat. Secara garis besar berbagai program yang kami rencanakan baik yang bersifat fisik maupun nonfisik, telah terlaksana dengan baik termasuk beberapa kegiatan tambahan dan insidental.

\section{Dampak bagi masyarakat}

Dampak dari program yang telah kita laksanakan bagi masyarakat ialah adanya Antusias yang tinggi dari masyarakat terutama pada anak-anak dilingkungan sekitar Kp. Kananga. Memiliki semangat yang berkobar dalam diri masing-masing, adanya memotivasi warga maupun anakanak dari hal program yang kami laksanakan di sekitaran Kp. Kananga. evaluasi, terciptanya rasa kekeluargaan, dan mengetahui tentang segala hal yang baru.

\section{SARAN}

a. Masyarakat hendaknya membantu dan menyukseskan apa yang telah menjadi program bersama sehingga akan terasa manfaatnya oleh masyarakat. Dan program bersama hendaknya terus dijalankan dan dilanjutkan meski KKN telah berakhir per 05 September 2018.

b. Perlu dihilangkan persepsi masyarakat bahwa mahasiswa KKN sebagai penyandang dana. Tetapi sebagai motivator, inovator dan dinamisator dalam melaksanakan program yang ada di masyarakat.

c. Meneruskan dan melaksanakan program kerja yang telah dijalankan oleh mahasiswa KKN.

\section{REFERENSI}

Budiati, A. (2018). Efektivitas Pembelajaran Kooperatif Tipe Think Pair Share untuk meningkatkan Hasil Belajar IPA di MTSN Gondowulun , 66.

Eska Perdana Prasetya (2017), Pemberdayaan Masyarakat Tentang Kesehatan, Pendidikan Dan Kreatifitas, Jurnal Abdi Dosen

Haneda. (2016). Mari Membiasakan Menabung Sejak Dini . Retrieved from BPR Haneda: bprhaneda.co.id/main/marimembiasakan-menabung-sejak-dini/

Hanipah, S. (2016). . Penerapan Pendidikan Agama Islam Pada Anak Usia Dini di Paud Nurul Islam Kota Pagar Alam , 124.

https://halimsamawa.wordpress.com/2013/0 7/31/laporan-akhir-kkn-tematik/

http://eprints.uny.ac.id/28760/1/Laporan\%2 0KKN\%201040.pdf 